\title{
Pupils' Digital Literacy Reflected in Teachers' Attitudes Towards ICT: Case Study of the Czech Republic
}

\author{
Lukas Cirus $^{1} \cdot$ Ivana Simonova ${ }^{2}$ (D) \\ Received: 18 October 2020 / Accepted: 4 March 2021 / Published online: 22 April 2021 \\ (c) The Author(s), under exclusive licence to Springer Nature Singapore Pte Ltd 2021
}

\begin{abstract}
The article deals with the development of digital literacy in primary school learners. Particularly, it focuses on reflection of teacher's type in reaching digital literacy of the primary school pupils. The contribution is considered from the view how (fast) teachers' adopt innovations in this field. Rogers' Diffusion of Innovation Theory is applied on an intentionally selected sample of Czech primary school teachers $(N=167)$. Applying the tool designed by Kankaanrinta and based on the Rogers' theory, teachers were structured into five groups (Innovators, Early adopters, Early majority, Late majority, Laggards) and the null hypothesis was tested stating that the level of digital literacy with the primary school learners does not depend on the teacher's type (according to the Rogers' typology of diffusion of innovation). Consequently, the increase in knowledge of learners $(N=173)$ was considered for each type of teachers through didactic pretest and posttest, each consisting of 18 tasks. For the purpose of testing, a special environment was designed to avoid any impact of learners' previous knowledge on the results, and a Dell Latitude notebook was set as a hardware platform. The software part was based on the open-source software exploiting Xubuntu 15.10 operational system developed on Ubuntu/Linux basis. The findings proved learners' results depended on the type of adopter of innovations in their teachers.
\end{abstract}

Keywords Diffusion of innovations · Innovator · Early adopter · Early majority $\cdot$ Late majority $\cdot$ Laggards $\cdot$ Primary education

\section{Introduction}

Every day, great acceleration can be seen in all fields of human activities. However, the strongest impact is in the field of technological innovations, e.g. the combination of Industry 4.0 and IT process relations, big data system, or the Internet of Things. Thus the role of digital literacy as the ability to use information and communication technologies

This article is part of the topical collection "Innovation and Technology for Smart Learning” guest edited by Lam-for Kwok, Junjie Shang, Shinichi Sato and Richard Li.

Ivana Simonova

ivana.simonova@osu.cz

Lukas Cirus

lukas.cirus@ujep.cz

1 Faculty of Education, Jan Evangelista Purkyne University, Ceske mladeze 8, 40096 Usti nad Labem, Czech Republic

2 Faculty of Education, University of Ostrava, F. Sramka 3, 70900 Ostrava, Czech Republic
(ICT) to find, evaluate, create, and communicate information is even increasing [1]. Both cognitive and technical skills are necessary for reaching digital literacy. The digital literacy includes (a) computer literacy, defined as the ability to communicate or find information on digital platforms [2], (b) information literacy, defined as a set of integrated abilities encompassing the reflective discovery of information, (c) the understanding of how information is produced and valued, and (d) the use of information in creating new knowledge and participating ethically in communities of learning [3].

From the educational point of view, we definitely agree that "the role of school should not be decreased in the time of artificial intelligence" $[1,4]$ because of the fact ICTs are an unnecessary part of the instruction [5]. Technologies provide strong support to teachers who work as innovation leaders, both within the face-to-face instruction in the classroom and after the lessons [6].

Problems relating to dissemination, resp. diffusion of innovations, have been the topic of numerous empirical studies, and important theoretical and practical findings have been discovered since the beginning of the twentieth 
century [7], e.g. those by Gabriel Tarde, father of modern sociology and social psychology, whose theory of imitation started researches on the penetration of innovations to the society [8]. Nevertheless, it was Everett M. Rogers who in 1962 published his research results on the diffusion of agricultural innovations in Iowa and introduced the Diffusion of Innovation Theory [5].

Primarily, Rogers' model of diffusion of innovations did not relate to education. According to Leeflang, first, it was applied to behavioral marketing models of market analysis describing ways of diffusion of innovation among consumers. These models can predict the volume of innovation sales in time and correlate characteristics of innovated reality, consumer of the innovation, and variables of marketing mix on the process of innovation diffusion [9]. The models are based on long-time researches on the adoption and diffusion of innovations [10] and they should be able to make quantitative prognosing on the consumer who decides about purchasing the product, resp. accepting the innovation [7]. From this viewpoint of diffusion of innovations, Rogers' model was applied in the field of education to show how innovations are accepted by teachers.

Particularly, in this research, we focus on teacher's type when adopting innovations in relation to the level of digital literacy in the primary school pupils.

Sahin [11, 14] finds Rogers' diffusion of innovations theory to be the most appropriate for investigating the adoption of technology in educational environments. However, Rogers (2003) was not always consistent in using words "technology" and "innovation" as synonyms. The adoption means for Rogers $[8,17]$ "full use of an innovation as the best choice of action available" and rejection is a decision "not to adopt an innovation". Diffusion is defined as "the process in which an innovation is communicated thorough certain channels over time among the members of a social system" $[5,8]$. As expressed in this definition, innovation, communication channels, time, and social system are the four key components of the diffusion of innovations.

\section{Theoretical Background}

From the theoretical point of view, the Rogers' Diffusion of Innovation Theory is the basis of the research. Rogers defines the term diffusion as the process via which the innovation is communicated to other subjects of a certain social system within a certain information channels [5]. The term of communication also means a certain type of process; the type where participating persons create and share information among themselves so as to reach mutual understanding [8].
Reflecting on the above mentioned, Rogers defined four basic components of diffusion: innovation, communication channels, time, and social system.

The entire process of diffusion of innovations is an interdisciplinary problem [12]; except of the socioeconomic approach, the geographic, or space view can be applied. In the Rogers' model, an object or process is innovative if it is considered to be new, not being new objectively or subjectively. Just the consideration of the newness determines the reaction of an individual on it, and at the same time, the rule is applied that if the idea seems to be new to the individual, it is an innovation. The innovation itself does not have to be immediately adopted by the whole society. An important barrier to the successful adoption of innovation is an uncertainty factor which is influenced by e.g. results of innovations. Rogers defines them as changes happening to an individual or the whole society in direct relation to acceptation or rejection the innovation [8]. The uncertainty can be lowered by being informed correctly and in detail about the advantages, limits, and risks of the innovation so that the individuals can form their own opinions [11].

The core of the innovative decision-making process is formed by the information search and processing activities which step-by-step motivate the individual to be able to decrease own uncertainty on the appropriateness or inappropriateness of the innovation to the accepted minimum level [8].

Additionally to the Rogers' innovative decision-making process, there exist other types of decision-making processes, e.g. dealing with the efficiency and effectiveness of innovations, or the increase of return rate of investments [13].

Rogers states that members of a certain social system do not acquire innovations at the same time but within a certain time period [5]. Reflecting this fact, they can be categorized according to the moment, when they apply the innovation for the first time [8]. Rogers classifies innovation adopters into five categories-Innovators, Early adopters, Early majority, Late majority, and Laggards.

- Innovators are eager individuals who like trying new things while disponing considerable financial sources to bear the costs of their cosmopolitan lifestyle. These sources then cover potential losses caused by unsuccessful innovation adoptions. The innovators are able to accept a rather high uncertainty rate with innovations; and although they are often not understood by other members of the social system, they open doors to the process of penetration of innovations.

- Early adopters are the most probable leaders who are often questioned by other members of the social system about innovations and new ideas, as they are-compared 
to the innovators-much more integrated in the structures of the social system.

- Early majority forms an important piece of diffusion chain together with early adopters, when playing the role of mediator of the uncertainty rate in the process of diffusion of innovations in the social systém. They also play the role of leaders but the time period of innovation decision-making process is much longer in comparison to the innovators and early adopters.

- Late majority consists of skeptics applying innovations from the reason of economic necessity and social pressure of the environment, and if the innovation is not against directions and rules of their social system. Until this is clear, they do not invest any sources.

- Laggards are characterized as traditionalists preferring non-innovative solutions and values; if finally they acquire an innovation, it mostly happens in the time, when it is step-by-step replaced by another new idea [8].

In each category, members express similar level of innovativeness [8]. Compared to this, Braak describes the innovativeness as a relatively stable, socially-built and innovation-related characteristics which signalizes the individual's good will to change practices [14]. Thus the innovativeness is the key to understanding the required and substantial behaviour within the innovation decision-making process, which is the basis of categorization. Characteristics of each category of adopters from the view of (1) personal features, (2) position in the society, and (3) relation to ICT are displayed below (Table 1).

\section{ICT Adoption by Czech Teachers}

In 2001 the international research SITES M2 (Second Information Technology in Education Study) [16] was conducted which focused on characteristic ways of ICT exploitation in educational institutions in 28 participating countries, incl. the Czech Republic. Results proved that (1) there was a growing amount of teachers who expressed positive attitudes to technologies and (2) the ICT started changing the traditional way of teaching. The ICT implementation in the process of instruction resulted into the shift in using teaching methods and approaches [16]. In 2015, Chraska [17] published a comparative study based on data collected in 2004 and 2015. He used 16 statements of own construction to detect teachers'attitudes to ICT and the questionnaire by Kankaanrinta [15] to discover teachers' typology according to the Rogers' theory. In 2004, the research sample included 125 teachers from 22 schools in one Czech region. In 2015, another group of 85 respondents was included from identical region (number of schools was not mentioned). One of the findings in 2004 was that Czech teachers were not

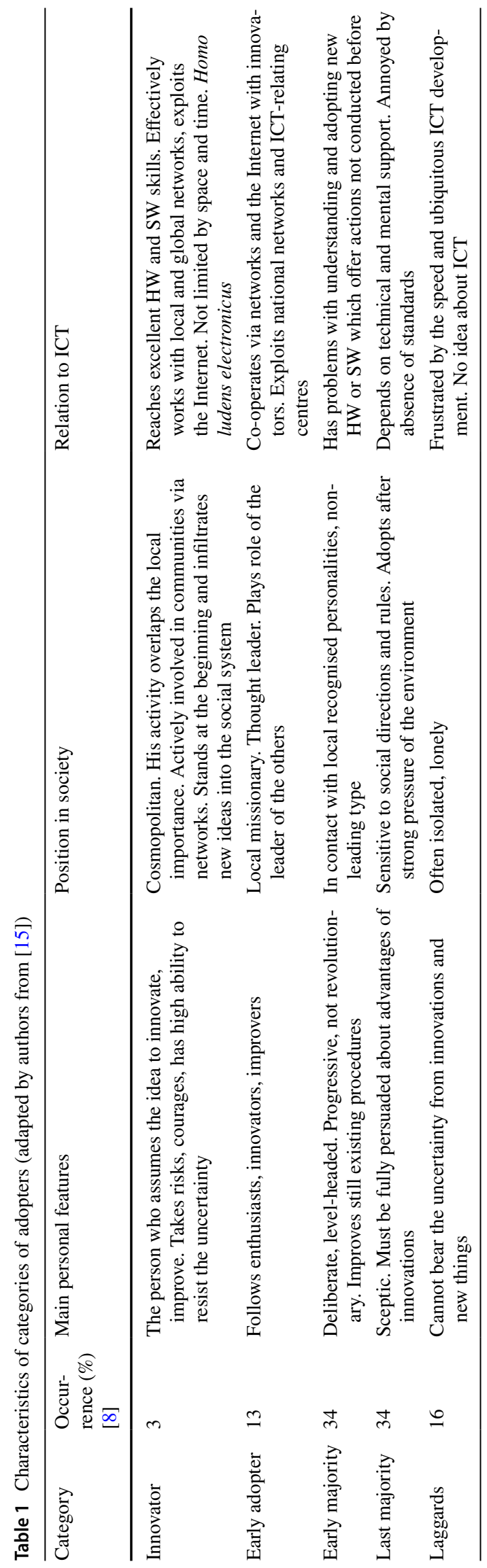


structured into five groups as designed by Rogers but that they rather formed two vague groups (clusters), similarly to digital natives and digital immigrants defined by Prensky [18]. In 2015, the classification of teachers followed Rogers' theory of five types of ICT adopters.

In 2009, another research was conducted in the Czech educational environment by Zounek and Sedova [19]. The findings proved the Rogers' typology when detecting five groups of teachers within 404 respondents in a Czech region (not identical with the one where Chraska conducted the research). Both the qualitative and quantitative research methods were applied in the research, e.g. questionnaires and analyses of video-recorded lessons among others.

\section{Methodology}

We expect that developing a higher level of digital literacy with the primary school learners is influenced (instead of others) by the rate of using and exploiting ICT in lessons by the teachers (e.g. through interactive boards, tablets, smartphones etc.). It can be expected that (reflecting the Rogers " typology) innovators will exploit technologies in the process of instruction more frequently and intensively, and will lead their learners to use them. Compared to this, laggards will be more conservative and they will rather use traditional methods of instruction, not those supported by ICT. This research problem was inspired by works dealing with the impact of teachers' innovativeness in natural sciences on the level of learners' natural science literacy, e.g. [12, 20-22]. We modified the focus of these studies on the research of teachers' innovativeness in the digital literacy with focus on ISCED 1 level, where the basics of literacy are formed with primary school children (aged 6-11). Research question of the conducted study is defined as follows: Does the way of adopting innovations by teachers (according to the Roger's Diffusion of Innovation Theory) make an impact on forming digital literacy with the primary school learners?

Under the Czech conditions, our research problem is based on the causal research by Zounek and Sebera [5] who deal with the impact of teacher type on the process of learners' digital literacy development-the competencies are under the attention both in the school and after-school environment because they work as the basis of other competencies developments.

The main research objective is to answer the question whether teachers'attitudes towards adopting innovations in the field of ICT are reflected in the level of pupils' digital literacy, particularly whether pupils whose teachers adopt innovations faster reach better results in digital literacy.

Reflecting on the research objectives, the null hypothesis was set and tested by the methods of inductive statistic data analysis. The methods reflect the expectation that the rate of innovativeness with the primary school teachers makes an impact on the pupils' digital literacy. In other words, it can be expected that the higher level of teachers' innovativeness is, the better pupils taught by these teachers are in digital literacy.

$H 1_{0}$ : The level of digital literacy with the primary school learners does not depend on the teacher's type (according to the Rogers' typology of diffusion of innovation).

The level of digital literacy is expressed in didactic test scores.

\section{Methods and tools}

Following methods were applied within the research: (1) Explorative research method, exploiting the questionnaire by Kankaanrinta as the tool; (2) Testing method, exploiting the didactic tests.

Teachers' attitudes towards ICT were monitored by the standardized questionnaire designed by Kankaanrinta to detect the five categories of adopters. The questionnaire was standardized for the Czech language within the project conducted by Černochová, Siňor, Kankaanrinta [23]. The questionnaire consists of 55 statements structured into three parts. Part 1 focuses on the use of ICT in primary education. It includes 25 items organized in five sets of statements containing five statements each. Respondents expressed their dis/agreement on a six-level scale: 5-I agree, 4-I rather agree, 3-I do not know, 2-I rather disagree, 1-I disagree, $\mathrm{N}-\mathrm{I}$ do not know. Scores were calculated for each set and the type of adopter is determined by the highest score in a set. Part 2 of the questionnaire concentrates on what teachers think about the use of ICT in primary education. It consists of 18 statements which are evaluated on an identical scale. Part 3 of the questionnaire comprises of 12 statements which monitor teachers' attitudes towards ICT use at the primary education level. Identically to Part 1 and 2, a six-level scale is applied to each statement.

Pupils' level of digital literacy was measured by didactic tests. The entrance level was detected by Pretest; Posttest was applied to measure the final level. Each didactic test included 18 tasks covering the following fields: basic terminology in ICT; the use of computer and file administration; the work with graphical editors (on the principle of e.g. SW Painting); the work with presentation; the work with text editor; the work with the Internet, and communication. The maximum score is 100 . The set of 18 tasks and a protocol on record of observed activities were available for each testing person. The testing person was not the teacher but an independent researcher. The testing person was allowed to provide support to the test person 
(learner), if asked. Then, in the protocol, it was mentioned with each task whether the learner worked independently or was supported in any way, or any other comments could be added in the protocol. Reflecting the Czech Framework Educational Programme for Basic Education (FEP BE) [24], the focus and expectations with each task cover the following contents and outputs: ICT-5-1-01 (the use of basic standard functions of computer and the most common peripheries), ICT-5-1-02 (rules on safe work with hardware and software), ICT-5-1-03 (protection data from damage, loss or abuse), ICT-5-3-01 (work with text and image in the text editor and graphical editor). After handing the closed notebook with fully charged battery to the pupil, they switched it on, and the recording (tracking) and measuring the time started. The following tasks were solved:

1. To find out a weekday with a concrete data to test the work with Calendar.

2. To work with folders - to find pupil's own folder in folder Dokumenty [Documents] and create own one called by their surname.

3. To find the icon of graphical editor and start the editor.

4. To exploit tools of the editor and draw a simple house with a garden, fence and tree.

5. To start up the Internet browser.

6. To minimize the window of the Internet browser and switch over to the graphical editor.

7. To save the created image of a house in the folder (see task 3) and call it dum [house].

8. To finish the work with graphical editor.

9. To find the icon of text editor, open it and write a simple text, e.g. about the activity after coming home from school.

10. To write a dictation of three sentences read by the testing person.

11. To save the text document in the folder (see task 3 ) and call it text [text].

12. To finish the work with text editor.

13. To find the programme for creating presentation, start it up and create a simple presentation on any topic, e.g. My interests; to save the presentation into the folder (see task 3) and call it prezentace [presentation].

14. To copy the folder [surname] on the flash drive, re-call it Jméno_Př́íjmení [Firstname_Surname] and disconnect the flash drive. Then, go back to learner's own folder and remove it to Trash.

15. To open the folder Dokumenty [Documents], find the folder called by your Firstname_Surname and remove it to Trash.

16. To find any computer game, start it up and play for approximately two minutes.
17. To find out the state of battery charge and hand the notebook to the administrator reporting the battery state.

\section{Tool for testing the pupils' digital literacy}

Our objective was to design such an environment which takes into account learners' age characteristics, i.e. it can be exploited for testing digital literacy in the primary school age. Our design is based on the Czech Framework Educational Programme for Basic Education (FEP BE) [24]. We designed a generic system so as to exclude previous knowledge and skills which respondents might get from exploiting concrete operational systems. Therefore, Dell Latitude was used as the hardware platform. The notebook used is a common device which works as a touchpad and trackpoint. Additionally, a mouse was available to the respondents. The notebook could be switched off in two ways - either using the key, or the icon within the operational system. For the purpose of testing, the notebook was battery-charged. The flash drive was part of the test set.

The software part was completely based on the opensource software using the operational system Xubuntu 15.10, which is a free, community-developed operational system designed on the basis of Ubuntu and GNU/Linux [25]. The design reflects the safety requirements, which minimizes risks of been infected by a virus, or of other violation.

From the graphical aspects, we adjusted the user's environment Xfce so that it did not contain any graphical elements similar to concrete applications or elements of a certain system. For example, for 'Start', not any icon of MS Windows was used, but so called 'hamburger icon' or 'hot dog' icon which are exploited by numerous current web pages and mobile applications for displaying the menu.

The distribution of graphical interface was designed so as it reflected conventions and possibilities of current operational systems. In the bottom part, the toolbar with the key 'Start' to open the menu is situated; icons and names of running applications are displayed there. In the right part of toolbar, the 'notification area' is situated; icons informing about the charging of the battery, computer network, date and time are displayed there. Clicking on the date, Calendar is displayed, as well as icons of single applications and folders. After switching on the notebook, the operational system starts working and the user is automatically logged into the graphical interface. Applications were re-named so as they did not remind of any concrete ones, e.g. the icon for starting the programme for designing presentations is not called 'PowerPoint', but 'Prezentace' [Presentation]. However, not only the names and icons were changed but also the environment of applications was adjusted, e.g. to the Impress application for designing presentations within the package 
of LibreOffice. Software equipment is mainly based on following programmes (all of them are of open source type, so they can be adjusted and exploited free of charge for research and commercial purposes):

- Operational system Xubuntu 15.10; environment Xfce (including in-built applications for the administration of files and games);

- Office package LibreOffice;

- Graphical editor Pinta (the environment is similar to Microsoft Paint);

- Programme for recording the screen Avconv, which is part of the Libav project;

- Authors' own scripts directing the recording process.

In the graphical environment, all user's activities are automatically tracked and saved in the video file. The programme runs automatically on the background and does not indicate its activity in any way. Thanks to this, the respondent is not influenced by another graphical element. Thus pupils do not know their activities are tracked, and do not change their behaviour, they work as usual. After finishing the work, the respondent hands the notebook to the administrator who presses keyboard shortcut and closes the tracking process. The recording is saved in MPEG-4 format and the date and time of tracking are included. The graphical interface of the testing system is displayed in Fig. 1.

\section{Research process}

Several steps led to reaching the research objective:

(1) the questionnaire by Kankaanrinta was applied at the Czech primary school teachers to get the typology according to the Rogers ' diffusion of innovation theory (innovators, early adopters, early majority, late majority and laggards);

(2) criteria were defined for selecting teachers in whose classes learners will be researched, and the classes were selected;

(3) in selected classes, to detect levels of learner digital literacy by Pretest at the end of the 3rd grade, to teach the learning content during the 4 th grade, to administer the Posttest at the end of the 4th grade, and to calculate the difference in test scores, i.e. the increase in knowledge within pupils' digital literacy.

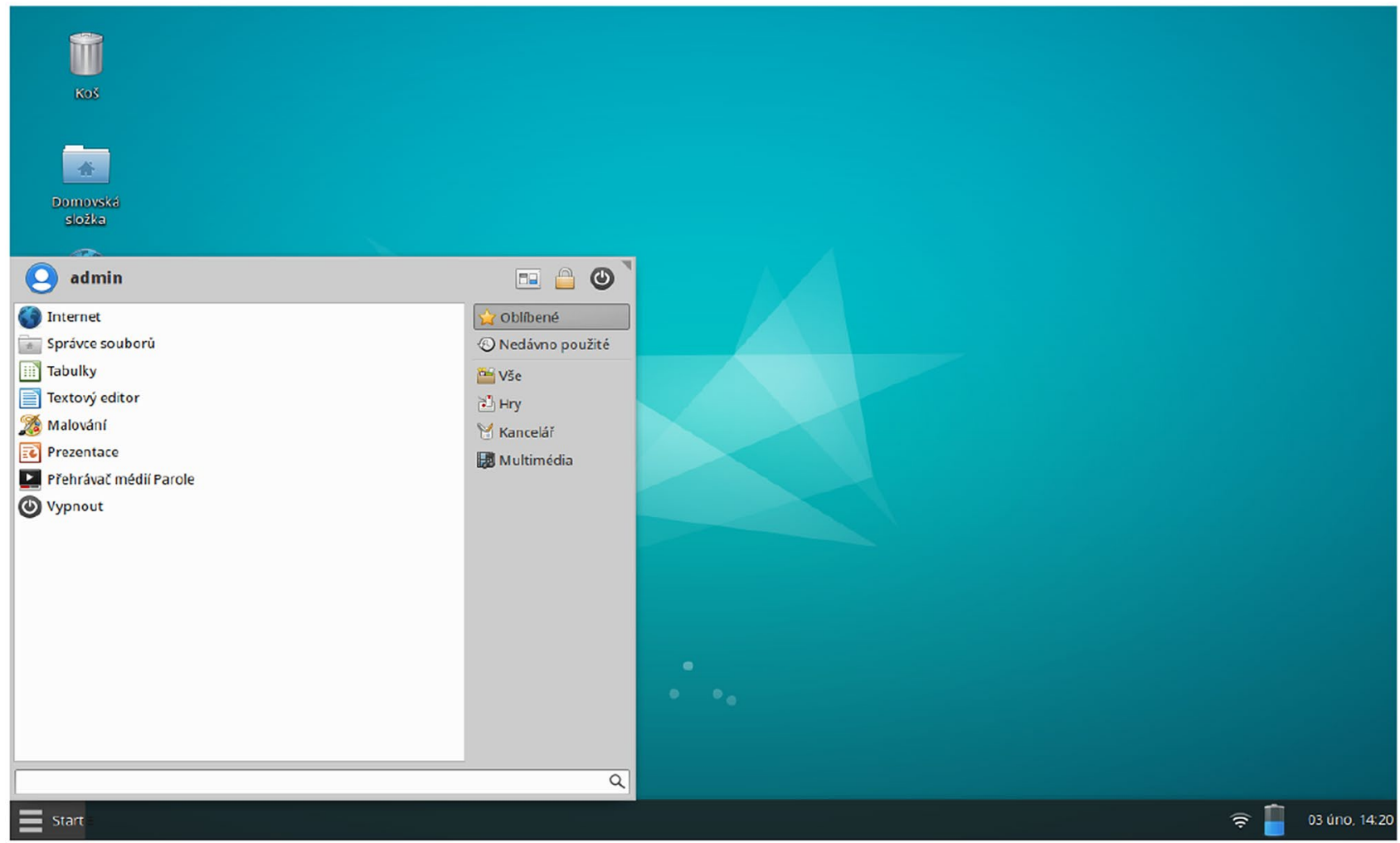

Fig. 1 Graphical interface of the testing system 


\section{Research samples}

Teachers'sample was formed within a selected region of the Czech Republic-Northern Bohemia. All primary schools within the area were addressed through their headmasters and pre-service teachers having teaching practice there. There were two basic preconditions the teacher could be included in the research sample: (1) teaching the thirdgraders in the school year and planning to teach them in the next year as fourth-graders, (2) subject of Informatics was included not earlier than in the fifth grade of the school curriculum. At the beginning, 181 teachers were included in the research sample. However, 14 of the did not return the questionnaire, or they did not fill it in correctly/completely. Finally, the research sample $(N=167)$ included 161 female teachers (96.4\%) and six male ones (3.6\%), 157 of them (94\%) having full qualification, i.e. master degree in teaching, 136 respondents were teaching at urban schools $(81,4 \%)$, eight respondents at sub-urban schools $(4.8 \%)$, 12 respondents at rural schools $(7.2 \%)$, and 11 respondents $(6.6 \%)$ worked at schools with multi-grade classes (i.e. where learners of more than one grade are taught together in one class). The gender structure, teacher qualification and type of primary school follow the data reflecting the state of primary education in the Czech Republic [26-29] which can be compared to statistics on teachers in the population.

Pupils'sample included 173 primary school learners of 3rd and 4th grades $(N=173) ; 89$ girls $(51.4 \%)$ and 84 boys $(48.6 \%)$ who were taught in ten classes. The classes were proportionally selected from all the classes of teachers participating in the research. The selection followed the structure of teachers' sample (five categories of teachers according the Rogers' Diffusion of Innovation Theory teaching in 3rd grade and consequently in the 4th grade, in urban, sub-urban, rural, multi-grade schools). The structure of pupils' sample is displayed in Table 2. Parents or legal representatives of pupils participating in the research were informed and expressed consent before the research started.

\section{Results}

The statistic processing was based on testing the null hypothesis. The entire search was done by the upper and lower fence method and by Grubbs test, which works with normal distribution data. The detection of outlier values was conducted. The Shapiro-Wilk normality test was applied for testing the null hypothesis. Consequently, appropriate parametric, or non-parametric statistic methods were used. Results are presented in two parts dealing with (1) the structure of teachers' types according to the Rogers' typology, (2) pupils' pretest scores reflecting teachers' types according to the Rogers' typology, (3) pupils' posttest scores reflecting teachers' types according to the Rogers' typology, and (4) comparison of pretest and posttest scores in pupils of particular teachers' types.

\section{Ad 1) Structure of teachers' types according to the Rogers' typology}

The final sample included 167 respondents. The structure of teachers' research sample is displayed in Table 3. As clearly seen in the table, Early majority group is the largest one (56.3\%), followed by innovators (15.5\%) and late majority $(12.6 \%)$.
Table 2 Structure of pupils

Table 3 Structure of teachers

\begin{tabular}{|c|c|c|c|c|c|c|c|c|c|c|}
\hline \multirow[t]{2}{*}{ Grades } & \multicolumn{2}{|c|}{ Innovator } & \multicolumn{2}{|c|}{ Early adopter } & \multicolumn{2}{|c|}{ Early majority } & \multicolumn{2}{|c|}{ Late majority } & \multicolumn{2}{|c|}{ Laggards } \\
\hline & $3 \mathrm{rd}$ & 4 th & $3 \mathrm{rd}$ & 4 th & $3 \mathrm{rd}$ & 4 th & $3 \mathrm{rd}$ & 4th & $3 \mathrm{rd}$ & 4 th \\
\hline$N$ & 16 & 18 & 18 & 17 & 18 & 16 & 17 & 18 & 16 & 18 \\
\hline Total & 34 & & 35 & & 35 & & 35 & & 34 & \\
\hline
\end{tabular}

\begin{tabular}{lrrrrrrrrrr}
\hline Type of adopter & $\mathrm{N}$ & $\mathrm{N}(\%)$ & $\mathrm{M}$ & $\mathrm{F}$ & Fully qualified & $\begin{array}{l}\text { Non- } \\
\text { quali- } \\
\text { fied }\end{array}$ & Urban & Sub-urban & Rural & Multi-grade \\
\hline Innovator & 26 & 15.5 & 0 & 26 & 26 & 0 & 25 & 0 & 0 & 1 \\
Early adopter & 17 & 10.2 & 1 & 16 & 17 & 0 & 11 & 0 & 5 & 1 \\
Early majority & 94 & 56.3 & 3 & 91 & 87 & 7 & 75 & 5 & 7 & 7 \\
Late majority & 21 & 12.6 & 0 & 21 & 20 & 1 & 19 & 1 & 0 & 1 \\
Laggard & 9 & 5.4 & 2 & 7 & 7 & 2 & 6 & 2 & 0 & 1 \\
\hline
\end{tabular}

$N$ absolute occurrence, $N(\%)$ relative occurrence, $M$ male, $F$ female 


\section{Ad 2) Pupils' pretest scores reflecting the teachers' type according to the Rogers' typology}

Reflecting the normal distribution of data, the analysis of variance (ANOVA) was applied for testing the null hypothesis: $F=0.799 ; p=0.53$. The result states that the null hypothesis cannot be rejected at the probability level 0.05 . This means there is no statistically significant difference between pupils' pretest scores reflecting the teachers' type according to the Rogers' typology. The values oscillate closely to 70 points (out of 100). The highest non-outlier values are below 90 points and the lowest outlier values are closely below 50 points. The variation range in all groups is close to 40 points. The data distribution shows some differences, however, in accord with our expectation we can conclude that differences in pupils' pretest scores in groups reflecting the teachers' types are not statistically significant.

\section{Ad 3) Pupils' posttest scores reflecting the teachers' type according to the Rogers' typology}

The analysis of variance (ANOVA) was conducted to test the null hypothesis: $\mathrm{F}(N=173)=21.66 ; p=0.00$. Contrary to the pretest scores, statistically significant differences $(p<0.05)$ were detected in pupils' posttest scores. Therefore, post hoc analysis based on least significant difference (LSD) test was conducted. Probability values of particular teachers' types are displayed in Table 4.

The null hypothesis can be rejected with pair comparisons at $p=0.05$ probability level. Statistically significant differences were detected in pupils' posttest scores reflecting teachers' types according to the Rogers 'typology. Compared to the pretest scores, the trend of decreasing mean values from innovators to laggards is discovered in posttest. In other words, pupils of teachers-innovators and teachersearly adopters have significantly higher test scores in posttest compared to pupils of teachers-late majority and teacherslaggards. These results proved our expectations. The trend to higher scoring is detected with pupils of teacher-early adopters; however, if the results of post hoc analysis are considered, there is no statistically significant difference between pupils of teachers-innovators and teachers-early adopters at 0.05 significance level. From the view of variation range, the difference was detected between pupils of teachers-innovators and teachers-late majority against pupils of teachers-late majority and teachers-laggard. The same difference was observed in the values of the interquartile range. It reflects the state, when pupils of teachers-innovators and teachers-early adopters show equal performance based on the higher level of their digital literacy. Contrary to this, the performance of pupils of teachers-late majority and teacherslaggards is more unstable.

\section{Ad 4) Comparison of pretest and posttest scores in particular teachers' types}

Reflecting the normality of data distribution, the pair $t$ test was applied at the probability level 0.01 . The null hypothesis was rejected at 0.01 in all researched fields. Results are displayed in Table 5.

These differences are clearly visible in the following quartile graphs, in which differences in pretest and posttest scores are compared reflecting the teacher's type according to the Rogers ' typology. Results are displayed in Fig. 2.

When comparing pretest and posttest scores with pupils of teachers-innovators, the statistically significant increase in mean values is detected after one year of teaching. We expected a visible shift to higher scores in posttests, however, the posttest results were rather surprising - the oscillation around the mean value is very narrow We can speculate on teachers' impact on pupils through the ICT-creative environment and the whole field of digital literacy supporting the development of pupils' competency can be attractive for pupils of teachers-innovators.

As in the previous type of teachers, the pupils of teachersearly adopters also show a statistically significant difference in mean values in pretest and posttest scores. The posttest

Table 5 Probability levels (p-levels)

\begin{tabular}{ll}
\hline & Probability level \\
\hline Innovator & $p=0.00$ \\
Early adopter & $p=0.00$ \\
Early majority & $p=0.00$ \\
Late majority & $p=0.00$ \\
Laggards & $p=0.00$ \\
\hline
\end{tabular}

Table 4 Post hoc analysis of pupils' posttest scores reflecting the teachers' type according to the Rogers' typology

\begin{tabular}{llllll}
\hline Posttest & Innovator & Early adopter & Early majority & Late majority & Laggard \\
\hline Innovator & - & $p=0.36$ & $p=0.07$ & $\boldsymbol{p}=\mathbf{0 . 0 0}$ & $\boldsymbol{p}=\mathbf{0 . 0 0}$ \\
Early adopter & $p=0.36$ & - & $\boldsymbol{p}=\mathbf{0 . 0 1}$ & $\boldsymbol{p}=\mathbf{0 . 0 0}$ & $\boldsymbol{p}=\mathbf{0 . 0 0}$ \\
Early majority & $p=0.07$ & $\boldsymbol{p}=\mathbf{0 . 0 1}$ & - & $\boldsymbol{p}=\mathbf{0 . 0 0}$ & $\boldsymbol{p}=\mathbf{0 . 0 0}$ \\
Late majority & $\boldsymbol{p}=\mathbf{0 . 0 0}$ & $\boldsymbol{p}=\mathbf{0 . 0 0}$ & $\boldsymbol{p}=\mathbf{0 . 0 0}$ & - & $p=0.08$ \\
Laggard & $\boldsymbol{p}=\mathbf{0 . 0 0}$ & $\boldsymbol{p}=\mathbf{0 . 0 0}$ & $\boldsymbol{p}=\mathbf{0 . 0 0}$ & $p=0.08$ & - \\
\hline
\end{tabular}




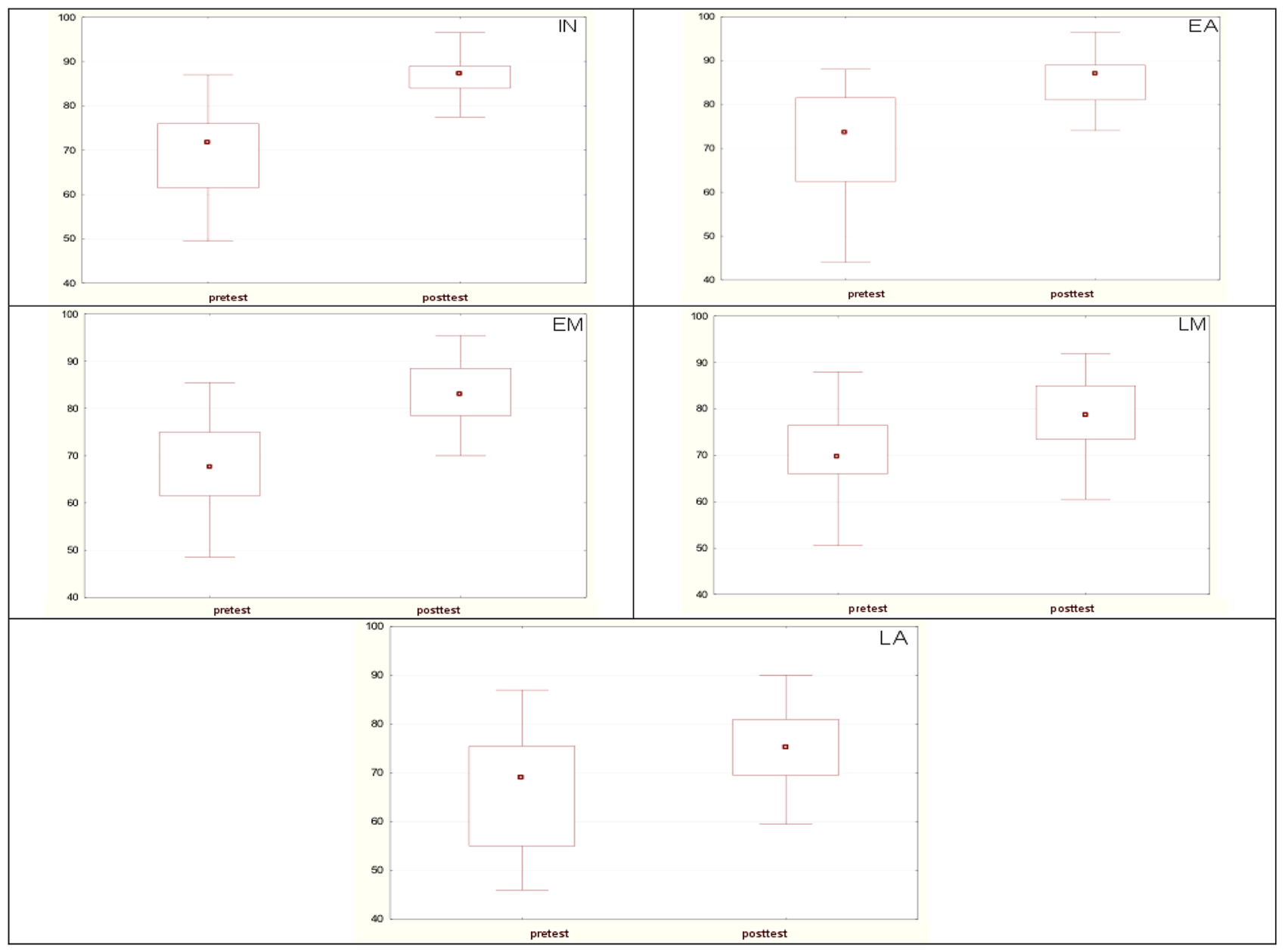

Fig. 2 Comparison of pretest and posttest scores with pupils of teachers-innovators (IN, upper left), early adopters (EA, upper right), early majority (EM, middle left), late majority (LM, middle right), and laggards (LA, bottom centred)

scores are still, even not much, more homogenous than in pretest scores.

In the group teachers-early majority, the increase in mean values of pupils' posttests is detected, however, it is not so sharp. Reflecting previous results, an increase in post-test scores in this group was expected. The reasons are identical to previous types of adopters.

With pupils' of teachers-late majority, the increase of mean values in post-test scores is clearly visible. The shift to higher post-test scores was expected. We can speculate that the environment, mostly the social environment (family, peers), may provide a stronger impact on pupils than their teachers' type of adopter can do.

The increase in mean values of post-test scores was discovered even in the group of pupils of teachers-laggards. The shift towards higher post-test scores was expected from the same reason as with the pupils of teachers-late majority.

When comparing all the pupils'test scores we can state that the level of digital literacy increased with most pupils in all groups within the school year. It is clearly visible that the increase of pretest and posttest scores is decreasing from pupils of teachers-innovators to teachers-laggards. The highest non-outlier values were reached by pupils of teachersinnovators, and the lowest non-outlier values were detected with pupils of teachers-late majority and laggards.

\section{Conclusion}

The research results show that there exists statistically significant impact on the way how teachers adopt innovations on the level of pupils' digital literacy. The difference (increase in knowledge) between pupils' pretest and posttest scores of teachers-innovators is 15.5 points (out of 25), as well as of teachers-early adopters; it is 14 points with pupils of teachers-early majority, nine points with pupils of teachers-late majority, and six points with pupils of and teachers-laggards. In other words, the results show that teachers-innovators, early adopters and early majority are rather close to each other, particularly by the willingness to implement ICT in 
the primary education. Analogically, teachers-laggards and late majority are close to each other by their feeling they reject ICT (to some extent).

When comparing our results to Chraska [17], they are rather similar to those based on data collected in 2015, not to those from 2004 when respondents were classified into two groups only (see Prensky [18]). However, a deeper analysis of Chraska's data [17] discovered that inclusion in a group did not relate to respondent's age, IT competencies, or the length of teaching practice. Chraska expected that mostly older teachers with longer teaching experience would belong to the group of laggards, having hardly any digital competencies. However, he discovered that this expectation was not proved-being classified as a laggard did not relate to the above-mentioned criteria. More likely, the decisive factor was teacher's personal preference connected with an individual style of teaching. And, younger teachers detected as laggards were mostly those who preferred nature to using ICT in common life $[15,17]$. At the end of the text Chraska promised to continue the research but he did not publish any results on this topic before 2020. A more important fact is that the research sample in [17] was described as "elementary school " teachers; however, in reality, when continue reading the description you discover respondents were not the "elementary ", i.e. primary, school teachers who are under the focus in our research, but lower secondary school ones $[15,17]$. This fact disqualifies the research from comparison to ours.

Moreover, in research by Zounek and Sedova [19] the sample is also not described in detail; they did not declare properly whether the primary school teachers were included in the sample as well.

Additionally, in 2014, Rogers' typology was applied by Zavrelova [29]. She also administered the Czech version of questionnaire by Kankaanrinta [15] as we did. Zavrelova analyzed the results of 151 primary school teachers from three regions of the Czech Republic (95.4\% females, most of them having teaching practice between 11-30 years, $92.7 \%$ fully qualified). She detected $17.9 \%$ of teachers-innovators, $5.3 \%$ of early adopters, $63.6 \%$ of teachers-early majority, 9.9\% of late majority, and $3.3 \%$ of laggards in the sample. These findings are similar to ours, mostly in the amount of teachers-early majority, innovators and teachers-late majority. The curve reflecting the findings by Zavrelova is more sharp compared to our results.

The future of education is connected to ICT; therefore, teachers' opinions and attitudes are crucial for the implementation of innovations (i.e. ICT in this case) at the primary school level. The high occurrence of innovators (15.5\%) forms a firm basis for further implementation of ICT. Teachers thus can be considered a highly progressive group within the process of adopting innovations and in their application in practice.
Results of this research should be reflected in pre-service teacher preparation and in-service teacher training. Moreover, strong change should be made within the curricula of courses dealing with Didactics (teaching/learning) for primary school teachers. Not only ICT skills but also a wider approach should be applied, paying attention to the development of primary school pupils' digital literacy. Both the pre-service and in-service teachers should be led to appropriate exploitation of ICT in education, building their positive attitude to ICT, which would lower the occurrence of teachers-late majority and laggards, and improving pupils' digital literacy. For in-service teacherslaggards special courses should be designed to eliminate their fears and negative attitudes to ICT (usually applied on both common life and education). For the primary school teacher the enthusiasm and motivation are more important than deep knowledge and skills in ICT exploitation. And, as the Czech primary school environment is specific by high occurrence of female teachers (94\%) [27], appropriate didactic training reflecting the gender structure should be applied because female teachers are mostly those making innovators from young learners. The requirement for training can be supported by the fact that having the ability to exploit technologies in private life does not mean at all that the individual is able to use technologies for educational purposes [30]. In other words, it is crucial to have the didactic competency to succeed in implementing technologies in the process of instruction.

Currently, in the times of COVID-19 pandemic, the role of ICT in education at all levels has sharply increased. Preservice and in-service teacher training in applying distance instruction is required not only by state documents and acts but by most of the teachers. Act N. 349/2020 Coll. on distance education [31], which is in force since 20 August 2020 in the Czech Republic, states that distance instruction is compulsory for learners at all school levels. However, hardly any in-service teacher of middle and higher age was trained in teaching in this way. As mentioned above, for younger teachers who are good at using ICT for private purposes, it does not mean they are competent enough for implementing the technologies into instruction. And, for primary school, the training in ICT didactics for both the teachers and learners is the main requirement for the future of their education.

Funding This research was funded by the Specific Research project N. SGS 43231152001 01. Lukas Cirus received the research grant from the Faculty of Education, Jan Evangelista Purkyne University.

\section{Declarartions}

Conflict of interest The authors declare that they have no conflict of interest. 
Ethical approval The article is an extended version of paper L. Cirus and I. Simonova, "Rogers' Diffusion of Innovation Theory Applied on Primary Education: Case Study of Czech Teachers," 2020 International Symposium on Educational Technology (ISET), Bangkok, Thailand, 2020, pp. 33-37, https://doi.org/10.1109/ISET49818.2020.00017.

\section{References}

1. The American Library Association. https://literacy.ala.org/digit al-literacy/. Accessed 12 Oct 2020.

2. An Overview of Basic Computer Literacy Skills. Harper College. http://dept.harpercollege.edu/gedstudy/handouts/computer_liter acy_skills.pdf. Accessed 12 Oct 2020.

3. The Association of College and Research Libraries (ACRL). http://www.ala.org/acrl/standards/ilframework. Accessed 30 Jan 2019.

4. Kartous B. Vzdělávání 4.0 jako reakce na Průmysl 4.0. Česká škola [Education 4.0 as reaction on Industry 4.0][online]. Praha: Albatros Media, 2017. http://www.ceskaskola.cz/2017/02/vzdel avani-40-jako-reakce-na-prumysl-40.html. Accessed 24 Sept 2020.

5. Zounek J, Sebera M. Budoucí učitelé a inovace v oblasti informačních a komunikačních technologií [Prospective teachers and innovations in the field of information and communication technologies]. Studia Paedagogica. 2005;10:95-108.

6. Schleicher A. sSchools for 21st-Century learners: strong leaders, confident teachers, innovative approaches. Paris: OECD Publishing, 2015. http://istp2015.org/documents/istp2015_oecd-backg round-report.pdf. Accessed 23 Jan 2020.

7. Vasil’ová M. Využitie kvantitatívnych metód analýzy trhu vybraného produktu [The exploitation of market analysis methods with a selected product]. Dissertation thesis. Bratislava: Ekonomická univerzita; 2012.

8. Rogers EM. Diffusion of innovations. 5th ed. New York: Free Press; 2003.

9. Leeflang P, Wittink D, Wedel M, Naert PA. Building models for marketing decisions. [Rev. and expanded ed.]. Dordrecht: Kluwer Academic Publishers; 2000.

10. Trommsdorf V, Steinhoff F. Marketing inovací [Marketing of innovations]. Praha: C.H. Beck; 2009.

11. Sahin I. Detailed Review of Rogers' Diffusion of Innovations Theory and Educational Technology-Related Studies Based on Rogers' Theory. TOJET : The Turkish Online Journal of Educational Technology, 2016, vol. 5, iss. 2, pp. 14-23. http://tojet.net/ articles/v5i2/523.pdf. Accessed 06 Jan 2020.

12. Szczyrba Z, Klapka P, Kunc J, Tnev P. Difúzní procesy v prostředí českého maloobchodu [Diffusion processes in Czech retail business]. In: Regionální studia. Olomouc: UPOL, 2017, pp. 8-12. http://geography.upol.cz/soubory/lide/klapka/szczyrba,klapk a,kunc,tonev.pdf. Accessed 06 Jan 2020.

13. Nelson RR. Why and how innovations get adopted: a tale of four models. Industrial and Corporate Change 2004, vol. 13, iss. 5, pp. 679-699. https://doi.org/10.1093/icc/dth027. ISSN 1464-3650. https://academic.oup.com/icc/article-lookup/doi/https://doi.org/ 10.1093/icc/dth027. Accessed 06 Jan 2020.

14. Braak JV. Individual characteristics influencing teachers' class use of computers. J Educ Comput Res. 2001;25(2):41-157.

15. Kankaanrinta IK. Finnish kindergarten student teachers' attitudes towards modern information and communication technologies. In:
Media M, editor. Time and Communication. Helsinki: University of Helsinki; 2000. p. 147-70.

16. Kozma RB. (ed.). Technology, innovation and educational change. IAEA, 2003.

17. Chraska M. The acceptance of ICT by teachers and its development between 2004 and 2015. J Technol Inf 7(2), 5-16. https:// doi.org/10.5507/jtie.2015.013. http://jtie.upol.cz/doi/https://doi. org/10.5507/jtie.2015.013.html. Accessed 06 Jan 2020.

18. Prensky M. Digital natives, digital immigrants. On the horizon 9(5), 2001. http://www.marcprensky.com/writing/Prensky\%2020Digital\%20Natives,\%20Digital\%20Immigrants\%20-\%20Part1. pdf. 2001; Accessed 06 Jan 2020.

19. Zounek J, Sedova K. Učitelé a technologie: mezi tradičním a moderním pojetím. [Teachers and technologies: between the traditional and modern concept]. Brno: Paido. 2009.

20. Coklar AN. Individual Innovativeness Level of Educational Administrators. In: Digital Education Review. 2012;22:100-110.

21. Jarvis T, Pell A. Effect of the challenger experience on elementary children's attitudes to science. J Res Sci Teach. 2002;39(10):979-1000.

22. Liu OL, Lee HS, Linn M. An investigation of teacher impact on student inquiry science performance using a hierarchical linear model. J Res Sci Teach. 2010;47(7):807-19.

23. Černochová $M$, Siňor $S$, Kankaanrinta IK. Jak přijímají budoucí učitelé novinky z oblasti informačních a komunikačních technologií? [How do pre-service teachers adopt innovations in the field of information and communication technologies?]. In: Nové možnosti vzdělávání a pedagogický výzkum. Ostrava: Ostravská univerzita; 2001.

24. Rámcový vzdělávací program pro základní školy [Framework Educational Programme for Basic Education, FED BS]. file:///C:/ Users/Simonova/Downloads/IM_RVP_ZV_EN_final_rijen08\%20 (1).pdf. Accessed 22 Jan 2020.

25. Xubuntu. http://www.xubuntu.org/about. Accessed 12 Oct 2020.

26. Český statistický úřad [Czech Statistical Office]. https://www. czso.cz/csu/czso/b1-zakladni-vzdelavani-poskytovane-na-zakla dnich-skolach. Accessed 12 Oct 2020.

27. Genderová problematika zaměstnanců ve školství [Gender problematics of employees in the field of education] Genderová problematika zaměstnanců ve školství, MŠMT ČR (msmt.cz)

28. Ústav pro informace ve vzdělávání [Institute for information in education], Kvalifikovanost učitelů - hlavní výsledky dotazníkového šetření [Qualification of teachers] Kvalifikovanost_ucitelu_ priloha.pdf

29. Zavrelova L. Primary school teachers'attitudes to using ICT in education. Diploma thesis. Supervised by Manenova M. 2014. 22740594 (theses.cz). Accessed 03 Feb 2021.

30. Simonova I, Poulova P. Social networks and mobile devices in higher education: pilot project. In: 2015 IEEE 39th Annual Computer Software and Applications Conference, Taichung, 2015, pp. 851-856. https://doi.org/10.1109/COMPSAC.2015.192

31. Act N. 349/2020 Coll. on distance education. sb140-20 3609..3624 (epravo.cz). Accessed 03 Feb 2021.

Publisher's Note Springer Nature remains neutral with regard to jurisdictional claims in published maps and institutional affiliations. 